\title{
Destruction of Immature Fish.
}

\author{
By \\ Gilbert C. Bourne, M.A., F.L.S., \\ Fellow of New College, Oxford, and Resident Director of the Association.
}

Among the questions on sea fishing which are periodically and pertinaciously brought forward by some people, there is none which is more persistently paraded before the public than the wholesale destruction by trawling and other means of immature food-fishes. When questions of this kind are brought forward they are invariably accompanied with demands for legislative interference, and in this instance it is demanded by some that beam trawling should be prohibited within the three-mile limit; by others that it should be prohibited altogether at certain seasons ; by others, again, that shrimp trawling should be forbidden; and a fourth party, with some show of reason, requires that certain specified areas should be closed against trawling for a number of years. It is unnecessary to say that if any of these prohibitive measures were adopted an important branch of the fishing industry would be seriously affected, and it is well, before any credence is given to the statements of those who agitate in this matter, that the whole subject should be put clearly before the public, that the extent and the deficiency of our knowledge should be made known, and that accurate observations should be placed alongside of and compared with the more random statements of the would-be legislators.

In point of fact, very few observations of scientific accuracy have been made. By far the most important contribution to the subject is the report of Prof. McIntosh, published in the Appendix to the Report of the Royal Commissioners on Trawling in 1885. In addition to this, observations are being made by the officers of the Fishery Board for Scotland, and some few have been made by the Marine Biological Association, of which it is proposed to give an account here.

Before proceeding further with the subject, it is well to clear up an ambiguity arising from the misuse of the word "immature." Strictly speaking, an immature fish is a young fish which has never developed ripe roe or milt. If it could be proved that great quan- 
tities of such fish were destroyed it might be conceivable that great damage is being done to sea fisheries, for young fish of all kinds have a great many enemies to contend with, and it is quite possible that man, by employing more numerous and more powerful engines for their destruction, might so diminish the number of breeding fish as to cause the young brood to be unable to cope with the numerous destructive agencies which beset them on their road to maturity. However this may be, and the case admits of much argument on both sides, the first question is whether such immature fish are in fact destroyed in vast numbers. It is just for this reason that a precise meaning should be attached to the expression "immature fish." An arbitrary standard of size is no criterion of the immaturity of different species of fish ; a turbot of ten inches length may be immature when a plaice or sole of the same length is filled with ripe ova, and there are some species of fish commonly used for food which seldom exceed ten inches in length, and in such cases many adult, that is to say, sexually mature specimens, fall below the arbitrary standard and are classed as "immature" or sometimes " undersized" fish. In making inquiries on this subject it is necessary that, by comparison of very many specimens, a minimum of size should be determined for the adults of each species of fish, so that it can be affirmed with tolerable certainty in each case that every fish below a certain size is really immature. Obvious as this may seem, it is necessary to insist upon it, for hitherto size and not sexual maturity has been the test of observers ; and even Prof. McIntosh's report, admirable in all other respects, leaves one in complete doubt as to whether the fish classed by him as immature were really sexually immature or merely undersized fish. It must be remembered, however, that the Professor had a very limited time in which to carry out his investigations, and that it would require long observation and experience to obtain the necessary data for determining at what average size different species of fish may be expected to come to maturity.

The importance of precision in definition will readily be understood after examination of Prof. McIntosh's report. In ninety-three hauls of the trawl 81,854 fish were taken, of which 11,613-a large proportion numerically-were classed as immature fish. But of these no less than 2956 were long rough dabs (Hippoglossoides limandoides), 6314 were common dabs (Pleuronectes limanda), and 1072 were combined common and long rough dabs. These two species of flat-fish are often small, never exceeding thirteen inches in length, and generally they are much smaller. It is probable that a large proportion of those taken by Prof. McIntosh were really mature, but small or undersized fish. But in any case the number 
of long rough and common dabs taken, whether mature or immature, is of no great importance. Neither species is valuable, and though eaten they are only sold at a very low price to the poorer classes of certain districts. Thus, of the whole number of 11,613 fish classed as immature, as many as 10,342 belonged to nearly worthless species.

Prof. McIntosh's observations were carried out on trawlers working in the ordinary course of business in the following localities: St. Andrews Bay, Aberdeen Bay, off Smith Bank, the Firth of Forth, off Scarborough.

Similarly Mr. Cunningham, the Naturalist of the Marine Biological Association, has made frequent observations on trawlers engaged in their business off Plymouth and westward to Mount's Bay. His experiences in all seasons and in all weathers coincide very closely with those of Prof. McIntosh. Very young flat-fishes are not captured in the large beam trawls working in depths of thirty to forty fathoms. Flat-fishes somewhat less than six inches in length are not uncommon, but they invariably belong to worthless or nearly worthless species, and of these no specimen under three inches long has been noticed.

The more valuable species of flat-fish taken by Plymouth trawlers are the sole (Solea vulgaris), turbot (Rhombus maximus), brill (Rhombus lævis), merrysole (Pleuronectes microcephalus), megrim (Arnoglossus megastoma), plaice (Pleuronectes platessa). Mr. Cunningham has never seen any of these species less than six inches in length brought up in the beam trawl. But there are several smaller species of little marketable value of which numbers of small specimens are commonly caught; these are flounders (Pleuronectes flesus), dabs (Pleuronectes limanda), thickbacks (Solea variegata), and scaldfish (Arnoglossus laterna). As the staff of the Marine Biological Association has been engaged on other problems, these fish have not been regularly counted and measured, but in the matter of flat-fish it is obvious that there is no difference between the north-east coast of England and Scotland and the channel near Plymouth. In both cases large numbers of undersized flat-fish are caught, and in both cases they are composed nearly exclusively of worthless species. The long rough dab (Hippoglossoides limandoides) is an exceedingly rare fish on the south-west coast of England, and its presence in the one and its absence in the other case forms the principal difference between Prof. McIntosh's results and those of the Marine Biological Association. In Prof. McIntosh's experiments 596 immature plaice were captured, and these principally in St. Andrews Bay, in depths varying between four and a half and twenty fathoms. It has been seen that very few small plaice are caught in the beam trawl at Plymouth, but quantities are caught by other means, as will appear later. 
Of immature round fish Prof. McIntosh captured an altogether insignificant number, the largest number being gurnards. Mr. Cunningham reports that small specimens of various species (whiting, pollack, pouting, hake, ling, doreys, and sea breams) are not uncommon in the contents of the large trawls, but he does not remember to have seen a specimen less than six inches in length. But the numbers of these small marketable fishes are altogether insignificant when compared to the cuckoo or boar fish (Capros aper), of which small species (it is less than six inches in length when full grown) vast numbers are sometimes caught. It is important to observe that round and flat fishes under six inches in length are caught in the large-meshed trawl, as it has often been maintained that soles and other fish of that size escape through the meshes. The conclusion with regard to flat fishes is that the young forms are not generally found in deep water, and that the large trawls do not and cannot destroy immature flat-fish. As for round fish it is known that when young they frequent rocky bottoms where the trawl cannot work, and their rarity in the trawl proves that they are not destroyed by it.

In fact no case has been made out against beam trawling. First it was attacked on the grounds that it was destructive of spawn, and this was speedily disproved; lately it has been attacked on the ground that it is destructive of immature fish, and this was disproved by the Royal Commissioners of 1883, whose conclusions have been confirmed at Plymouth ; the last possible grounds of attack were equally disposed of by the Royal Commissioners, and it would be well if agitators would now let beam trawling alone. The complaints made of the destruction of very young fish in bays and estuaries appear, however, to have more foundation in fact, though more knowledge is sadly required. It is well known that in summer in certain localities millions of very small fish are to be seen along the margin of the shore, and that they often perish in vast numbers through the drying up of tidal pools by the sun. They are also eaten by gulls and by other fishes. A certain proportion escape destruction, and, according to their species, seek different habitats during their adolescence. It is an open question whether man can possibly destroy such a quantity of very young fish as to make any difference to the number of those that come to maturity. Often as it has been insisted upon, the public does not appear to realise that every female fish that comes to maturity lays a prodigious number of eggs; that if millions of these perish before hatching, or before they come to maturity after they are hatched, there will still be as many or even more adults left as the parents from which they had their origin, and that in spite of the seemingly enormous waste, the number of the species is kept up. That this is the case is familiar to all students of natural history, but 
it would seem to be hardly understood by the majority of well-informed people who are not naturalists.

The Royal Commissioners of 1863, 1878, and 1883 have all come to the conclusion that the destruction of very young fry by man is so very small relatively to its prodigious destruction by other agencies that it can make not the slightest difference to the total number of fish that survive. In point of fact, however, very little is known as to the numerical relation between fry killed by man and those destroyed by other agencies, and until accurate estimates are made in several localities, it is not possible to lay down a law on the subject.

Minute flat-fishes are not found on the rocky shores of Plymouth Sound, but there are several localities on the south coast where the conditions are favorable to the life of young fishes; such are Tor Bay, Whitsand Bay, and Mevagissey Harbour. The want of a suitable steamboat has prevented the staff of the Marine Biological Association from making the long and numerous expeditions to distant places necessary to the prosecution of this line of research, but with the help of Mr. Matthias Dunn they have gained a good deal of information about Mevagissey Harbour. Mr. Dunn sent some two dozen young flat-fish, about as large as a man's thumbnail, to the Laboratory in April, and since then Mr. Cunningham has visited Mevagissey and received several consignments of young fish. His experiences are given in his own words.

“ On May 15th I paid a visit to Mevagissey to see Mr. Dunn and examine the young flat-fishes which he had informed me were to be seen in large numbers in the harbour at low tide. The old harbour of Mevagissey is almost completely empty of water at low spring tides and it was in this condition when I was there; the bottom consists of soft mud or harder muddy sand, and in the inequalities of the surface were left pools of water and running streamlets. In these were myriads of young flat-fishes, most of them completely metamorphosed and of a dark colour, but a few transparent and still having an eye on each side of the head. Among them I found a few soles. The little fish were in constant motion, rising to the surface of the water and then going again to bottom and lying on or in the sand. They could be caught without difficulty by the hand or with a cup or with a muslin net. I found all except the soles were of one species, namely, the flounder (Pleuronectes flesus); the individuals of this species varied from $10 \mathrm{~mm}$. to $18 \mathrm{~mm}$. in length (three eighths to three quarters of an inch). The young soles were scarce, I caught only three specimens the day I was there, but Mr. Dunn sent me up fifteen more the next day; these were all about $14 \mathrm{~mm}$. in length (half an inch).

“ On May 31st Mr. Dunn sent up about a hundred more Pleuro- 
nectes flesus, and one small sole caught in the harbour at low tide as before. The sole was $18 \mathrm{~mm}$. long, the flounders 15 to $19 \mathrm{~mm}$. The difference represents the growth which had taken place in the fortnight elapsed. From the fact that after two or three days' search during these spring tides $\mathrm{Mr}$. Dunn was only able to find a single young sole, it may be inferred that after reaching the size of $18 \mathrm{~mm}$. the small soles move into somewhat deeper water, and are no longer to be found within the low-water mark of spring tides.

"I searched the shores of Sutton Pool and the mouth of the Plym estuary at Plymouth, and found no specimens of young flounders such as were so plentiful at Mevagissey; but some boys brought me two specimens of Pleuronectes flesus on May 31st, $10 \mathrm{~mm}$. long, taken at low water on the muddy shore of Sutton Pool."

There are three points of particular interest in this Report, first the preponderance of the comparatively worthless flounder over the valuable sole; secondly, the indication given of the rate of growth of both sole and flounder; thirdly, the inference as to the change of habits of the young sole. Much more information is required on the last two heads. Undoubtedly the minute fish migrate from the beach to deeper water in search of food, but next to nothing is known of their history and movements at this time. It is known that small flat-fish, between three and six inches in length, are commonly caught by shrimp trawls working in one to three fathoms of water, and by seine nets hauled inshore. It has already been pointed out that when undersized flat-fish are captured by large beam trawls, they almost invariably belong to small and valueless species ; and it is important to note that the same rule holds good, though in a lesser degree, for shrimp trawls, - at any rate it is so in Plymouth Sound.

The shrimp trawls used at Plymouth have an iron beam from nine to twelve feet long, and the mesh of the net is about half an inch square at the cod end. Whilst working at the life-history of the sole during the last twelve months, Mr. Cunningham engaged the shrimp trawlers of Plymouth to bring him all the small soles caught by them in the Sound. The number brought in was not large, never more than three or four in a day, and as a rule they were not brought in on more than one or two days in a week. Thus the take of undersized soles in Plymouth Sound is not large, and as the shrimpers at once throw overboard all the soles which are too small to be of market value, no destruction is done. On several occasions the fisherman of the Marine Biological Association has trawled in Cawsand Bay and elsewhere with the express purpose of getting very young soles. The results of his fishing are instructive, and the following cases may be regarded as typical. On August 15th, 1888, the trawl was shot several times in Cawsand Bay, where it was reported the shrimpers 
were catching and destroying " vast numbers" of small soles. Only one small sole, three inches in length, was taken, but with it were numbers of young scaldfish (Arnoglossus laterna), which may easily be mistaken for young soles on cursory examination. On May 8th of this year in the same locality several hauls of the trawl brought up, besides worthless gobies and dragonets, two specimens of Solea minuta, two and a half and three inches long, two dabs (Pleuronectes limanda) two or three inches long, and one scaldfish two inches long. Solea minuta is a distinct and absolutely worthless species, which never exceeds five inches in length ; it is commonly mistaken for a young sole. On May 9th the fisherman caught two marketable soles (seven inches and thirteen and a half inches long) below Plymouth citadel, and numbers of small dabs two inches long and upwards. On May 10th, trawling in the Cattewater, he took six Solea vulgaris, six and three quarter to seven and three quarter inches in length, and twenty-two dabs, one and three quarters to six inches in length. In August, 1888, the fisherman was instructed several days in succession to bring up to the Laboratory undersized flat-fish brought in by the trawlers. They all proved to be scaldfish (Arnoglossus laterna). At the time it was being reported that an immense number of young soles were being destroyed.

It seems to be clearly established that plaice under six inches in length congregate in large numbers in particular places, often referred to as " nurseries." They are caught in numbers at all depths less than twenty fathoms. Such a nursery has recently been discovered and described in Nature by the Fishery Board for Scotland, and it is remarkable that nearly the whole of the 596 undersized plaice taken by Professor McIntosh during his experimental trawling were captured in St. Andrews Bay. The largest number taken by him in one haul was 122 in four and a half fathoms of water, but the next largest numbers, 65 and 64, were taken in twelve and twenty fathoms respectively. The only "nursery" practically known by the Marine Biological Association is the estuary of the Plym, called the Cattewater. The fishing in the upper part of this estuary, from Oreston to Laira Bridge and upwards, is the private property of the Earl of Morley.

Fishing with seine nets last autumn, the lessee of the fishing, Mr. Henry Clark, Q.C., in seven hauls captured some 200 plaice less than seven inches long, together with others of larger size. All the small fish were returned alive into the water, and this is always done in this private water, but below Oreston, where the fishing is public, the small plaice are destroyed wilfully or through negligence. On the 16th of May Mr. Cunningham saw large numbers of young plaice (Pleuronectes platessa), herring (Clupea harengus), and pollack (Gadus 
pollachius) caught by the seine in the Cattewater. The plaice were about four and three quarter inches, the herring five and one eighth inches, long. They were about one year old, except the herring, which were probably hatched in the January previous, and all were taken away, none returned to the water. In the following week the fisherman of the Marine Biological Association was fishing with a seine in the same place, and, as before, a numerically large proportion of undersized plaice were captured, but were returned to the water. It is beyond question that large numbers of undersized fish are destroyed by seines every year in the Cattewater, and from information received it appears that this is the case in many other localities. But it would be necessary to make continuous and careful observations before it could be asserted that such fishing is injurious and ought to be prohibited.

It appears from what has been said above that the Marine Biological Association is not acquainted with any "nursery" of young soles. It is stated that such nurseries do exist on various parts of the English and French coasts. Investigation should be made, and if such nurseries can be proved to exist on the English coast it would doubtless be proper to prohibit fishing there, since soles require protection more than any other fish. It is strongly suspected that quantities of young soles are destroyed every year in certain creeks in the estuary of the Thames. Faversham Creek is an example, but scientific evidence is required before any steps are taken, as these "young soles" may prove to be thickbacks (Solea variegata) or other species.

Young turbots and brill (Rhombus maximus and $R$. lævis), three quarters to an inch in length, are found floating at the surface of the sea. Mr. Cunningham has examined several such in the early part of June, and Mr. Dunn, of Mevagissey, finds them floating at the surface every year. Mr. Cunningham considers that these fish are little more than a month old, and that their pelagic habit is due to the fact that they possess a large air bladder. It is unnecessary to say that their habit at this age protects them from trawling in any form.

A consideration of this report will lead to the inference that the destruction of immature fish has been greatly exaggerated by persons interested in some particular branch of fishing. Destruction doubtless does occur, but in the case of very small fry it is an open question whether it is injurious. The destruction of plaice must be determined before it can be asserted that it is injurious, and the destruction of very small soles is not proven. But it is evident that in spite of the work already done an immense quantity of accurate information is still needed, and this the Marine Biological Association hopes, in 
the course of its work, to supply. During the past year they have been unable to gather more than scattered and often chance pieces of information, but as soon as they are equipped with the means necessary to so extended an investigation, no effort will be spared to obtain data of the highest possible accuracy. 